\title{
Field-Scale Evaluation of Biological Uranium Reduction and Reoxidation in the Near-Source Zone at the NABIR Field Research Center in Oak Ridge, TN
}

\author{
Criddle, Craig S. \\ Stanford University
}

RESULTS TO DATE: SUMMARY OF RESEARCH PROGRESS (through September 30, 2004)

Field tests began August 24, 2003 (Day 1). The work included an above ground treatment system to remove nitric acid, $\mathrm{Ca}$ and $\mathrm{Al}$ from groundwater and a nested well system to test uranium reduction and immobilization. We have now performed field tests of biostimulation for over 404 days, and the work continues. We have achieved the major goals of the field tests i.e. bio-reduction of $\mathrm{U}(\mathrm{VI})$ to $\mathrm{U}(\mathrm{IV})$ and immobilization of uranium in situ.

\section{START-UP AND OPERATION OF FBR SYSTEM}

The above ground treatment system is designed to remove highly concentrated nitric acid, $\mathrm{Ca}$ and $\mathrm{Al}$ from groundwater and provide proper environmental conditions for in situ bio-reduction and immobilization of uranium.

On Day 1, we inoculated the field scale biological fluidized bed reactor (FBR) with microbial denitrifying culture enriched from the FRC groundwater. For the next week we worked on stabilizing the reactor for nitrate removal. Ethanol was used as electron donor for denitrification. After start-up, the reactor (height $3.05 \mathrm{~m}$; diameter $0.76 \mathrm{~m}$ ) was operated continuously for 137 days. Groundwater extracted from extraction wells was treated to remove nitrate then re-injected to subsurface. Ca and Al were removed by pretreatment in the precipitation tanks. The influent nitrate concentration of the system was as high as 200 $\mathrm{mM}$ at the beginning and eventually decreased to $2-3 \mathrm{mM}$ as the groundwater in the well system was cleaned-up by clean water flashing. The effluent nitrate concentration was below $0.6 \mathrm{mM}$.

The FBR system then was operated periodically to treat the groundwater from a down gradient well and the treated water was injected into the outerloop injection well together with supplemental tap water in order to maintain a positive groundwater flow. The influent nitrate was about 20-30 mM and the effluent nitrate was below $0.1 \mathrm{mM}$.

WELL TEST SYSTEM OPERATION The well system used for the bio-treatment consists of four wells of 4 inch in diameter and three multiple level sampling wells (MLS well).

The well system is designated as follows: Well A (FW103): outer loop extraction well Well B (FW026): inner loop extraction well Well C (FW104): inner loop injection well Well D (FW024): outer loop injection well

MLS wells (FW100, FW101, and FW102): ports 1-4 indicate the four deepest sampling ports (1 is $45 \mathrm{ft}$ from ground surface; 2 is $40 \mathrm{ft}$; 3 is $35 \mathrm{ft}$; and 4 is $30 \mathrm{ft}$ ). The work has been performed in four phases. The basic strategy was to ensure that conditions ( $\mathrm{pH}$, nitrate, calcium) are suitable for $\mathrm{U}(\mathrm{IV})$ reduction and then to immobilize uranium in situ via biological reduction of $\mathrm{U}(\mathrm{VI})$ to $\mathrm{U}(\mathrm{IV})$.

PHASE 1: FLUSHING TO REMOVE ALUMINUM, CALCIUM, AND BULK NITRATE WITH ACIDIFIED WATER (DAYS 9 - 68) 
During this period, groundwater extracted from wells $\mathrm{A}$ and $\mathrm{B}$ was treated aboveground supplemented with tap water, adjusted to $\mathrm{pH} 4.0$, then injected into injection wells $C$ and $D$. The purpose of this low $\mathrm{pH}$ flush was to prevent chemical clogging by Al hydroxide.

From day 9 to 32, the flow rates were (LPM): 0.75 , outer loop extraction well; 1.5 , innerloop extraction well; 1.5, innerloop injection well; and 1.5, outer cell injection well.

From day 33 to 48, the flow rates were (LPM): 0.75, outer loop extraction well; and 1.5, outer cell injection well. No injection and extraction was performed in the innerloop.

From day 49 to 56 , the flow rates were (LPM): 0.75 , outer loop extraction well; 1.5 , innerloop extraction well; 1.5, innerloop injection well; and 1.5, outer loop injection well.

From day 57 to 60 , the flow rates were (LPM): 1.5, innerloop injection well; and 1.5, outer cell injection well. No extraction was performed.

From day 61 to 68 , the flow rates were (LPM): 0.45 , outer loop extraction well; 0.45 , innerloop extraction well; 0.9, innerloop injection well; and 0.9, outer loop injection well.

After two months of operation, nitrate concentrations of the groundwater decreased from $100 \mathrm{mM}$ or greater to around 1.0-2.0 mM. Ca and Al were significantly reduced, with Al levels below $10 \mathrm{mg} / \mathrm{l}$ and $\mathrm{Ca}$ levels below $60 \mathrm{mg} / \mathrm{l}$.

PHASE 2: NEUTRAL pH (6.0) WATER FLUSHING (DAYS 69-136) The objectives during this phase were: (1) to reduce the mobility of $\mathrm{U}(\mathrm{VI})$ within the test zone by increasing $\mathrm{pH}$ to a level where it sorbs strongly, and (2) to increase $\mathrm{pH}$ to a favorable range for denitrification.

Extraction and injection flow rates were the same as those used previously (LPM): the flow rates were (LPM): 0.45, outer loop extraction well; 0.45, innerloop extraction well; 0.9, innerloop injection well; and 0.9 , outer loop injection well.

After 128 days of flushing, the nitrate concentration in had decreased from $120 \mathrm{mM}$ to about $1 \mathrm{mM}$. Al and Ca concentration decreased from 550 and 900 to 6 and $40 \mathrm{mg} / \mathrm{l}$, respectively. Uranium concentration dropped from original $50 \mathrm{mg} / \mathrm{l}$ to $1-2 \mathrm{mg} / \mathrm{l}$ at $\mathrm{pH}$ 5.8-6.0.

\section{PHASE 3: IN-SITU DENITRIFICATION (DAYS 137-184)}

During this period, the extracted water from both innerloop and outerloop was directly re-injected to injection well. Because nitrate concentrations were low, operation of the FBR was not necessary. However, a vacuum stripper was installed between innerloop extraction well and injection well in order to remove nitrogen gas produced from in situ denitrification and to prevent clogging of the subsurface by nitrogen gas. From days 137-142, water extracted from well A (flow rate 0.44 LPM) was recycled to well D. Tap water was adjusted with $\mathrm{HCl}$ to $\mathrm{pH}$ 5.8-6.0 and injected into well $\mathrm{D}$ at 0.9 LPM. Water extracted from well $\mathrm{B}$ was adjusted to $\sim 6.5$ with a $\mathrm{K} 2 \mathrm{CO} 3$ solution, degassed with a vacuum stripper to remove dissolved nitrogen gas, and injected into well $\mathrm{C}$. At this $\mathrm{pH}, \mathrm{U}(\mathrm{VI})$ is mostly sorbed.

Ethanol addition to the subsurface began on Day 137 (January 7, 2004). Ethanol concentration in the injected water was adjusted to about $60-100 \mathrm{mg} / \mathrm{l}$ as COD. This was the first of 4 biostimulation runs to stimulate denitrification and remove residual nitrate. Each runs lasted about four days.

After each run, we stopped addition of $\mathrm{K} 2 \mathrm{CO} 3$ solution to determine the rate of rebound of nitrate and $\mathrm{U}(\mathrm{VI})$ levels. 
Extraction and injection flow rates were as follows: Outer loop extraction well A: $0.44 \mathrm{Ipm}$ Outer loop injection well D: $0.9 \mathrm{lpm}$ Interloop extraction well B: $0.44 \mathrm{lpm}$ Interloop injection well C: $0.44 \mathrm{lpm}$

Vacuum stripped water from well B was stored in a tank and sealed with a He headspace. During periods of ethanol addition, this oxygen-free water was mixed with an ethanol solution to achieve the desired concentration and injected into well $\mathrm{C}$.

Denitrification in the subsurface occurred after ethanol addition. Almost no soluble COD was detected in innerloop extraction wells, inicating that the added ethanol injected was consumed. Nitrate concentrations in MLS well quickly dropped to $0.1 \mathrm{mM}$ or lower during ethanol injection. When ethanol injection stopped, nitrate concentration increased but did not resturn to the stready state level before ethanol injection. After repeated injections, peak nitrate concentrations in MLS wells dropped to around $0.2 \mathrm{mM}$.

During this period, sulfate concentration in the MSL wells and innerloop extraction well was relatively stable, and there was no sulfide odor in the groundwater samples. Uranium concentrations did not show significant change during ethanol injection. This suggests that the ethanol consumption in the subsurface was mainly due to denitrification activity.

\section{PHASE 4: BIOSTIMULATION OF U(VI) REDUCTION (DAYS 185-404)}

Biostimulation of $(\mathrm{VI})$ reduction was observed during the fifth runs of ethanol injection between day 185 and 194 (February 24 to March 3, 2004). Thereafter, the ethanol injection was adjusted to enhance U(VI) reduction and immobilization of uranium in situ. Biostimulation by ethanol addition has been performed intermittently in 29 runs that have contnued through September 30. In order to prevent well and subsurface from clogging, ethanol injection was performed periodically, about once per week. The injection duration was 6 days at the beginning and gradually reduced to 24-48 hours after biological activity became well-established in the subsurface. During the ethanol injection, we added a K2CO3 solution to increase $\mathrm{pH}$ to 6.8 to 7.5 . The purpose of carbonate addition was to enhance bioavailability of $\mathrm{U}(\mathrm{VI})$. When ethanol injection stopped, we also stopped $\mathrm{pH}$ adjustment, and the $\mathrm{pH}$ decreased to its baseline level of 5.9-6.2. Under these conditions, uranium adsorption by the sediment is optimal.

During this period, the flow rates of extraction and injection wells were the same as previously. The $\mathrm{pH}$ in the innerloop extraction well was maintained around 5.8-6.2.

A stable anaerobic environment and anaerobic microbial population was eventually established surrounding the inner loop wells, as evidenced by:

1) Suspended sediment samples recovered from Well $C$ and MLS well (FW101-2) were black, indicating a reducing environment;

2) Sulfide was detected in MLS wells (FW101-2, FW101-3, and FW102-3) when ethanol was injected, indicating SRB activity;

3) SRB activity was maintained for weeks. Recent test indicated that after 2 week starvation (no ethanol injection), sulfide production occurred in MLS wells within 4 hours when ethanol was re-injected; Dissolved gas analysis failed to detect methane in groundwater samples during ethanol injection. This suggests that methanogenic bacteria may notbe present in appreciable numbers, although significant populations of SRB and FeRB are present.

The biological reduction and immobilization of uranium is supported by the evidence as follows. 
1) $U(\mathrm{VI})$ disappearance was observed during the 5th runs (day 185-194) and 6th runs (day 201-208). In the MLS wells, $\mathrm{U}(\mathrm{VI})$ concentrations were maintained the same or slowly decreased during ethanol injection but $\mathrm{U}(\mathrm{VI})$ concentration quickly rebounded when ethanol injection stopped.

2) Sulfate concentrations in innerloop extraction well decreased after day 190. Sulfate concentration in MLS well decreased in the presence of injected ethanol and rebounded after ethanol injection stopped. Sulfide was detected in MLS water. These observations indicate that a sulfate reducing community was present, and these communities are known to reduce $\mathrm{U}(\mathrm{VI})$.

3) After 250 day operation, we observed a rapid decrease in $\mathrm{U}(\mathrm{VI})$ concentration in MLS wells about 4 hours after ethanol injection. $\mathrm{U}(\mathrm{VI})$ concentrations slowly rebounded after ethanol injection stopped.

4) Before biostimulation, no $U(I V)$ was found in the sediments from the test area. After bio-stimulation, sediment samples were taken from innerloop injection well on day 258, 271,and 303. X-ray absorption near edge structure (XANES) spectra analysis indicated that the samples contained up to $42 \%$ of U(IV). This confirmed the bio-reduction of $\mathrm{U}(\mathrm{VI})$ by bio-stimulation.

5) $U(\mathrm{VI})$ concentrations in innerloop extraction well continuously decreased from $1.0 \mathrm{mg} / \mathrm{l}$ to $0.2 \mathrm{mg} / \mathrm{l}$. The $\mathrm{U}(\mathrm{VI})$ concentration in MLS dropped from $0.4-1.0 \mathrm{mg} / \mathrm{l}$ to around $0.1 \mathrm{mg} / \mathrm{l}$ or low. The uranium content in the sediments was still about $1000 \mathrm{mg} / \mathrm{kg}$ or higher. This suggests that uranium in the sediments was immobilized.

\section{MICROBIAL POPULATIONS IN THE SUBSURFACE}

The most probable enumeration number (MPN) method was used to monitor the microbial activity of denitrifiers, sulfate reducing bacteria (SRB) and iron reducing bacteria (FeRB) in the subsurface. $\mathrm{U}(\mathrm{VI})$ reduction can be performed by several species of FeRB and SRB. After biostimulation, significant levels of detrifiers, SRB and FeRB were observed in the innerloop wells. On day 357, the extraction well B contains (cell/ml): denitrifiers, 107; SRB, 106; and FeRB, 106. An inner loop MLS well contains (cell/ml): denitrifiers, 10E8; SRB, 10E6; and FeRB, 10E6. MPN results of a control well which has the same chemical composition as the test area but did not receive any biostimulation treatment did not show MPN number for both SRB and FeRB but had a low level of denitrifiers (cell/ml): 10E2. These results indicate that the steps taken at the site to enhance $\mathrm{U}(\mathrm{VI})$ reduction have increased the concentrations of typical $\mathrm{U}(\mathrm{VI})$ reducing populations.

DELIVERABLES: Wu, W.-M., B. Gu, M. W. Fields, M. Gentile, Y.-K. Ku, S. Tiquias, J. Nyman, J. Zhou, P. M. Jardine, and C. S. Criddle. 2004. Characterization of uranium (VI) reduction by microbial biomass from a denitrifying fluidized bed reactor. Submitted to Journal Bioremediation.

Gu, B., W.-W. Wu, M.W. Fields, M. V.Ginder, H. Yan, S. Fendorf, C.S. Criddle, and F. M. Jardine. 2004. Bioreduction of uranium in a contaminated soil column. Submitted to Environ. Sci. Technol.

Luo, J., W.-M.Wu, M.N.Fienen, P.M.Jardine, T.L. Mehlhorn, D.B. Watson, O.A.Cripka, C.S.Criddele, and P.K.Kitanidis.2004. Hydraulic analysis of in-situ reactors created by extraction-injection wells:a nested cell and its application at Oak Ridge,TN. Submitted to Groundwater.

Poster Gentry, T.J C.W. Schadt, X. Liu, L. Wu, W. Wu, C.S. Criddle, J.M. Carley, J.D. Istok, M. Sapp, S.L. Carroll, M.A. Bogle, R.F. Hickey, D.D. Watson, and P.M. Jardine, M.W. Fields and J. Zhou. 2004. Use of Integrated Microarray Technologies to Monitor Microbial Communities During the Remediation of a Groundwater System Contaminated with High Levels of Nitrate and Uranium. Poster presented at ASM 104th General Meeting, May, 2004. 
COLLABORATIONS: Oak Ridge National Laboratory - P. Jardine, C. Brandt, B. Gu, Z. Zhou Retec - B. Hickey Consultant - O. Cirpka 